\title{
UPAYA PERENCANAAN PENYELAMATAN KOLEKSI DALAM RANGKA MENGHADAPI BENCANA ALAM DI PERPUSTAKAAN FAKULTAS PETERNAKAN UNIVERSITAS GADJAH MADA (UGM) YOGYAKARTA
}

\author{
Musrifah \\ Sahidi \\ Nia Alinda \\ Program Studi Interdisciplinary Islamic Studies \\ Konsentrasi Ilmu Perpustakaan dan Informasi \\ Program Pascasarjana UIN Sunan Kalijaga Yogyakarta \\ Email: musrifah26@yahoo.com \\ Email: isyhad.borneo@gmail.com \\ Email: nia4linda@gmail.com
}

\begin{abstract}
Abstrak
Sebuah perencanaan terhadap bencana merupakan elemen yang penting dalam melakukan tindakan pencegahan dalam upaya penyelamatan di perpustakaan. Salah satu penyelamatan yang harus dilakukan di suatu perpustakaan adalah penyelamatan koleksi. Koleksi perpustakaan merupakan salah satu faktor utama dalam kualitas suatu perpustakaan. Inilah yang melatarbelakangi penulis untuk meneliti tentang Upaya Perencanaan Penyelamatan Koleksi dalam Rangka Menghadapi Bencana Alam di Perpustakaan Fakultas Peternakan Universitas Gadjah Mada (UGM) Yogyakarta. Metode yang digunakan dalam penelitian ini adalah metode deskriptif dengan pendekatan penelitian kualitatif, teknik-teknik yang peneliti gunakan dalam upaya pengumpulan data yaitu, observasi non partisipan, wawancara dan dokumentasi. Adapun hasil penelitian yang diperoleh tentang upaya yang direncanakan dalam menyelamatkan koleksi yang dilakukan oleh Perpustakaan Peternakan Univeritas Gadjah Mada yaitu ada empat (4) tahap. yaitu tahap pencegahan, tahap tanggapan, tahap reaksi, dan tahap pemulihan. Untuk proses penyelamatan koleksi dalam rangka menghadapi bencana alam di perpustakaan tersebut yaitu sebelum terjadinya bencana, melakukan back-up untuk koleksi yang di anggap penting, seperti repositori, back up data yang disimpan di tiga (3) server yang berbeda yaitu, di luar kota Yogyakarta, di server perpustakaan pusat dan disimpan oleh kepala Perpustakaan Peternakan Universitas Gadjah Mada (UGM) Yogyakarta. Adapun alat yang sudah tersedia untuk menyelamatkan koleksi dalam rangka menghadapi bencana alam hingga saat ini baru tersedia alat pemadam kebakaran yaitu dua unit alat pemadam kebakaran, satu unit pipa penyalur air, dan satu hydran yang digunakan untuk menyalurkan air ketika terjadinya kebakaran.
\end{abstract}

Kata kunci: Perencanaan, Bencana Alam, Koleksi, Perpustakaan. 


\begin{abstract}
A disaster planning is an important element in taking preventive measures in rescue efforts in the library. One of the rescues to be done in a library is the collection rescue. Library collection is one of the main factors in the quality of a library. This is the background of the author to examine the Efforts of Collective Rescue Planning in the Framework of Facing Natural Disasters in the Library Faculty of Animal Husbandry Gadjah Mada University (UGM) Yogyakarta. The method used in this research is descriptive method with qualitative research approach, techniques that researchers use in the effort of data collection that is, non participant observation, interview and documentation. The research results obtained about the planned in saving the collection made by the Library of Livestock Univeritas Gadjah Mada that there are four (4) stage. namely the stage of prevention, the response stage, reaction stage, and recovery phase. For the collection process in order to deal with natural disasters in the library that is before the disaster, back-up for collections that are considered important, such as repositories, back up data stored in three (3) different servers that is, outside the city of Yogyakarta, at the central library server and stored by the head of the Gadjah Mada University's Animal Husbandry Library (UGM) Yogyakarta. The tools that are available to save the collection in order to face natural disasters until now only available fire extinguishers are two units of fire extinguishers, one unit of water distribution pipes, and one hydrant used to distribute water when a fire occurs.
\end{abstract}

Keyword: Planning, Natural Disasters, Collection, Library. 


\section{PENDAHULUAN}

\section{A. Latar Belakang}

Fatmawati (2010:15) mengemukakan bahwa kehidupan umat manusia laksana perjalanan yang terus menghadapi perkembangan, tantangan dan perubahan, termasuk kehidupan perpustakaan. Memberikan layanan informasi kepada pemustaka atau masyarakat umum dengan mengutamakan kepuasan pengguna (customer satisfaction). Perpustakaan sebagai sumber informasi merupakan pintu gerbang pengetahuan yang menyediakan kebutuhan dasar bagi pembelajaran sepanjang hayat. Peran perpustakaan bagi pengguna atau pemustaka juga berubah seiring dengan kebutuhan penggunanya. Di dalam Undang-Undang Republik Indonesia Nomor 43 Tahun 2007 Tentang Perpustakaan. Perpustakaan adalah institusi yang mengumpulkan pengetahuan tercetak dan terekam, mengelolanya dengan cara khusus guna memenuhi kebutuhan intelektualitas para penggunanya melalui beragam cara interaksi pengetahuan.

Seperti yang kita ketahui bahwa perpustakaan berperan menyediakan dan menyebarkan informasi kepada pemustakanya. Perpustakaan memberikan solusi-solusi permasalahan yang dihadapi pemustaka terkait dengan kebutuhan informasi dalam kehidupannya. Oleh sebab itu, perpustakaan selalu berupaya menyediakan seluruh sumber-sumber informasinya kepada pemustaka, termasuk sumbersumber rujukan yang ada di perpustakaan. Menurut Undang-Undang Perpustakaan (UU nomor 43 tahun 2007) disebutkan bahwa perpustakaan adalah institusi pengelola koleksi karya tulis karya cetak, dan/atau karya rekam secara professional dengan sistem yang baku guna memenuhi kebutuhan pendidikan, penelitihan, pelestarian, informasi, dan rekreasi para pemakai.

Koleksi perpustakaan merupakan salah satu faktor utama dalam kualitas suatu perpustakaan, dan salah satu kriteria dalam penilaian layanan perpustakaan yaitu melalui kualitas koleksinya. Menurut Ade 
Kohar (2003:6) koleksi perpustakaan mencakup berbagai format bahan sesuai dengan perkembangan dan kebutuhan alternatif para pemakai perpustakaan terhadap media rekam informasi. Sebagai mana yang dikatakan oleh Lasa HS (2009:176), koleksi perpustakaan adalah semua informasi dalam bentuk karya tullis, karya cetak, dan/atau karya rekam dalam berbagai media yang mempunyai nilai pendidikan, yang dihimpun, diolah dan dilayankan. Di perpustakaan ada koleksi atau materi yang mudah digantikan. Namun ada pula koleksi perpustakaan yang sulit, bahkan tidak dapat tergantikan lagi. Persiapan menghadapi bencana perlu dilakukan, termasuk di perpustakaan. Disaster Plan merupakan suatu rencana tertulis tentang persiapan menghadapi kemungkinan timbulnya bencana. Persiapan ini bertujuan untuk meminimalkan kerugian materi atau jiwa yang mungkin timbul.

Dalam pengelolaan di perpustakaan seringkali perpustakaan hanya terfokus pada kegiatan hal-hal yang bersifat rutin di perpustakaan misalnya dalam hal layanan peminjaman, penelusuran informasi serta manajemen informasi, padahal selain aktivitas rutin tersebut, ada berbagai faktor bencana baik yang ditimbulkan oleh manusia maupun bencana alam yang mengancam keberadaan dan kelangsungan sumber-sumber informasi tersebut.

Alegbeleye dalam Issa di dalam artikelnya yang berjudul "Disaster Preparedness at the State Public Library Ilorin Kware State" mendefinisikan bencana di perpustakaan sebagai suatu peristiwa yang menghasilkan penghapusan tiba-tiba catatan dan dokumen dari aksesibilitas dan penggunaannya. Bencana dapat dianggap sebagai suatu kejadian yang sementara atau permanen, sehingga membuat informasi yang terkandung dalam dokumen terganggu atau tidak dapat diakses. Menurut Krihanta. (2013:5.14) sebagian orang atau masyarakat menganggap peristiwa bencana merupakan kehendak Tuhan atau taqdir yang tidak dapat ditolak maupun dihindari. 
Memperkirakan datangnya bencana alam bukanlah suatu pekerjaan mudah. Bencana alam bisa saja datang dengan tiba-tiba tanpa diketahui sebelumnya (unpredictable).

Bencana tersebut tidak dapat dihindari tapi dapat diprediksi, diantisipasi dan diminimalkan oleh manusia, bencana yang ditimbulkan oleh alam dan dapat mengancam koleksi perpustakaan diantaranya berupa gempa bumi, banjir, gunung meletus, kebakaran, serangga, hewan pengerat, dan jamur. Sedangkan bencana yang ditimbulkan oleh manusia dan mengancam koleksi perpustakaan yaitu kebakaran, pencurian dan berbagai tindak vandalisme.

Menurutt Clements (1990:37) pengelolaan terhadap bencana untuk menyiapkan suatu tindakan penyelamatan sebagai usaha pertama yang dilakukan dalam suatu institusi apabila sewaktu-waktu terjadi suatu bencana. Bencana yang dapat membahayakan di perpustakaan dapat berupa ulah manusia seperti pencurian, kurangnya pengamanan yang ada dalam institusi, kebakaran dan lain sebagainya. Selain itu bencana yang dapat mengancam dapat terjadi secara alami seperti gempa bumi, gunung meletus, badai dengan skala yang bervariasi.

Kenyataan di lapangan menunjukkan bahwa upaya perencanaan penyelamatan koleksi di perpustakaan yang dilakukan oleh perpustakaan Fakultas Peternakan Universitas Gadjah Mada (UGM) sudah dilakukan dengan semaksimal mungkin, sesuai dengan keadaan perpustakaan tersebut. Berdasarkan hal di atas, maka menjadi alasan bagi penulis untuk membahas bagaimana upaya perencanaan penyelamatan koleksi dalam rangka menghadapi bencana alam di Perpustakaan Fakultas Peternakan Universitas Gadjah Mada (UGM) Yogyakarta. Hal tersebut menjadikan Penulis tertarik untuk membahas hal di atas, sehingga penulis mengambil judul "Upaya Perencanaan Penyelamatan Koleksi dalam Rangka Menghadapi Bencana Alam di 
Perpustakaan Fakultas Peternakan Universitas Gadjah Mada (UGM) Yogyakarta”.

\section{B. Fokus Penelitian}

1. Upaya apa yang direncanakan untuk menyelamatkan koleksi dalam rangka menghadapi bencana alam di Perpustakaan Fakultas Peternakan Universitas Gajah Mada (UGM) Yogyakarta?

2. Bagaimana proses penyelamatan koleksi dalam rangka menghadapi bencana alam di perpustakaan Fakultas Peternakan Universitas Gajah Mada (UGM) Yogyakarta?

3. Alat apa sajakah yang sudah tersedia untuk menyelamatkan koleksi dalam rangka menghadapi bencana alam di Perpustakaan Fakultas Peternakan Universitas Gajah Mada (UGM) Yogyakarta?

\section{Tujuan Penelitian}

1. Untuk mengetahui upaya perencanaan penyelamatan koleksi dalam rangka menghadapi bencana alam di Perpustakaan Fakultas Peternakan Universitas Gajah Mada (UGM) Yogyakarta.

2. Untuk mengetahui proses penyelamatan koleksi dalam rangka menghadapi bencana alam di perpustakaan Fakultas Peternakan Universitas Gajah Mada (UGM) Yogyakarta.

3. Untuk mengetahui alat yang sudah tersedia untuk menyelamatkan koleksi dalam rangka menghadapi bencana alam di Perpustakaan Fakultas Peternakan Universitas Gajah Mada (UGM) Yogyakarta.

\section{TINJAUAN PUSTAKA}

\section{A. Pengertian Perencanaan dan Bencana Alam}

Sagala (2010:271) mengatakan bahwa perencanaan adalah proses memikirkan dan menetapkan kegiatan-kegiatan atau program-program yang akan dilakukan di masa yang akan datang untuk mencapai tujuan tertentu. Selanjutnya Lasa HS (2009:259), juga mengatakan bahwa perencanaan (planning) merupakan suatu proses penentuan dan 
pentahapan kegiatan yang akan dijalankan dalam rangka mencapai tujuan tertentu.

Bencana menurut Liga Palang Merah Internasional dalam Sulistyo-Basuki (2013:6.14) ialah situasi bencana (catastrophic situation) yang menyebabkan pola hidup sehari-hari tiba-tiba terganggu dan masyarakat terbenam dalam ketidakberdayaan dan menderita, akibatnya memerlukan perlindungan, pakaian, pemukiman, pengobatan medis, dan keperluan hidup lainnya. Definisi tersebut dapat disederhanakan menjadi sebuah peristiwa, waktunya tidak dapat ditentukan, dan mengakibatkan gangguan yang serius. Oleh karena itu, bencana mengakibatkan rekod/bahan pustaka tidak dapat diakses dan digunakan oleh pengguna.

Adapun pengertian bencana alam menurut Badudu dan Zain (1994:156) adalah bencana yang ditimbulkan oleh peristiwa alam seperti gunung meletus, banjir, angin topan dan sebagainya. SulistyoBasuki (2013:6.15) menyatakan bahwa dalam kaitannya dengan bencana, syogiannya dipahami arti risiko karena risiko berkaitan dengan bencana. Risiko adalah peluang dan konsekuensi dari peristiwa yang tidak diinginkan, terutama peristiwa yang berakibat cenderanya manusia, kerusakan harta benda, atau kerusakan lingkungan. Oleh karena itu, risiko berhubungan dengan kedekatan pada bencana dan nasib buruk. Risiko meliputi ketidakpastian mengenai apa yang akan terjadi dan dianggap ada dalam situasi sekarang, tetapi sedikit informasi tentang apa yang akan terjadi. Risiko bukanlah wujud yang dapat diukur dan risiko bersifat anstrak, istilah lain ialah hazard, dapat dianggan sebagai fenomena alam itu sendiri. Bencana adalah dampak gangguan pada manusia, harta benda, atau lingkungan. Oleh karena itu, bencana dianggap sebagai dampak negatif.

Menurut Krihanta (2013:5.15) Bencana dapat dibagi menjadi dua, yaitu bencana alam dan bencana akibat ulah manusia. Kedua jenis bencana ini dapat mengakibatkan kerusakan arsip/koleksi dalam 
jumlah yang sangat besar dan dalam waktu yang sangat singkat. Dari dikotomi ini, dapat dibedakan peristiwa yang tidak dapat dikendalikan manusia karena manusia tidak mengendalikannya, tetapi kadangkadang dapat meramalkannya. Bencana semacam itu ialah gempa bumi atau letusan gunung api. Selain itu, manusia dengan menggunakan sistem teknologi dapat mengendalikan sehingga terkendalikan. Namun, biasanya tidak dapat diramalkan, misalnya kebocoran gas akibat kelalaian manusia.

Dengan demikian, sebuah perencanaan terhadap bencana merupakan elemen yang penting dalam melakukan tindakan pencegahan dalam upaya penyelamatan. Inti dari rencana bencana meliputi pengetahuan tentang bangunan, identifikasi koleksi, pencegahan bencana, teknik pemulihan, ketersediaan bantuan dari luar, serta keberadaan suatu struktur pengambilan keputusan. Namun peran yang sangat penting dalam menghadapi bencana adalah manusia (petugas atau pengelola perpustakaan).

\section{B. Pencegahan Bencana Alam}

Muttaqin, dkk (2007:6) mengatakan bahwa mencegah bencana secara mutlak memang mustahil, namun setidaknya bencana tersebut bisa dikurangi kemungkinan terjadinya atau diminimalkan akibat yang ditimbulkan.

1. Kebakaran

Api merupakan ancaman bagi perpustakaan, sejak berabad-abad, dari semua bencana yang dapat merusakkan, bencana kebakaran nerupakan bencana yang potensial yang paling mampu menimbulkan kerusakan Perpustakaan terbesar dari zaman purba di Iskandaria yang didrikan pada abad ke-3 SM semasa Ptolomeus 1 dan diperluas oleh Ptolomeus II terbakar pada tahun 47 SM semasa Julius Caesar dan akhirnya terbakar lagi pada tahun 373. Sejumlah perpustakaan dunia Yunani Romawi rusak karena kebakaran. 
Sulistyo-Basuki (2013:6.15) menyatakan bahwa ada tiga unsur yang menimbulkan percikan api, yaitu sebagai berikut:

a. Bahan yang mudah terbakar terdapat di pusat recod kertas, bentuk mikro, pita magnetis, dan cekram optic.

b. Zat yang mempercepat pembakaran, yaitu zat asam.

c. Sumber percikan

Selanjutnya Sulistyo-Basuki (2013:6.23) menyatakan bahwa guna mengurangi risiko kebakaran, berbagai cara sederhana disarankan, yaitu antara lain:

a. Menggunakan alat yang digerakkan secara hastawi (manual), bukannya dengan mesin.

b. Menggunakan forklift berdaya gas bukannya listrik

c. Melarang penggunaan alat pemanas cangkingan (portable), hot plates, alat pembuat kopi, fotokopi, baterai charges, api patria tau las, dan sumber api lainnya.

d. Melarang penyimapanan bahan kimia, minyak, cat dan benda lain yang mudah terbakar.

e. Melarang merokok dan menyediakan asbak dekat ruangan

f. Membatasi ruangan simpan paling sedikit $30 \mathrm{~cm}$ dari sumber cahaya terdekat.

2. Banjir

Menurut WJS. Poerwadarminta (2011:96) banjir merupakan air bah yang meluap, yang banyak dan deras. Sedangkan menurut Sulistyo-Basuki (2013:6.18) air sama merusaknya dengan api, karena itu pencegahan terhadap banjir sama pentingnya dengan pencegahan terhadap kebakaran. Air tidak saja berupa banjir, melainkan juga dalam bentuk bocoran dari atap atau pipa leding. Indonesia sebagai Negara tropis sering kali menghadapi bahaya banjir, luapan air hujan, dan tergenang air pada waktu musim hujan. Oleh karena itu, penyimpanan bahan pustaka atau koleksi yang ada di perpustakaan perlu dibuat lebih tinggi daripada jalanan. Demikian pula dengan 
untuk penyimpanan koleksi harus memiliki batas penyimpanan minimum 10 sentimeter di atas lantai.

3. Gempa Bumi

Menurut Kamus Besar Bahasa Indonesia (1989:267) gempa yaitu peristiwa alam berupa getaran atau gerakan gelombang pada kulit bumi yang ditimbulkan oleh tenaga asal dalam. Menurut Krihanta (2013:5.14) gempa bumi merupakan peristiwa alam akibat adanya pergeseran bumi yang mengakibatkan perubahan pada struktur bumi di daratan. Gempa bumi menyebabkan semua fasilitas bangunan dan gedung yang tepat berada di atas struktural bumi yang mengalami perubahan tersebut hancur dan roboh. Sulistyo-Basuki (2013:6.18) menyatakan apabila lokasi penyimpanan bahan pustaka berada di daerah yang rawan gempa, maka penyimpanan tersebut harus memperhitungkan kemungkinan terjadinya gempa, maka gedung perpustakaan tersebut harus dibuat tahan gempa.

4. Gunung Berapi

Menurut Krihanta (2013:5.16) bencana gunung berapi biasanya didahului dengan peristiwa gempa bumi, kemudian diikuti dengan turunnya larva yang sangat panas (api). Gempa bumi yang disertai larva sangat panas ini tidak hanya menyebabkan kerusakan struktur bangunan dan gedung, tetapi juga menimbulkan ancaman bahaya kebakaran, baik dalam skala kecil maupun besar. Bahaya kabakaran ini lebih mudah terjadi khususnya pada bangunan-bangunan yang rentan terhadap panas dan mudah terbakar.

\section{Penyusunan Rencana Pencegahan Bencana}

Sulistyo-Basuki (2013:6.15) menyatakan bahwa rencana pencegahan dan pemulihan bencana harus memiliki sasaran yang jelas. Sasaran umumnya mencakup berikut ini:

1. Upayakan adanya metode yang efektif dan efisien dalam pencegahan kerusakan. 
2. Upayakan adanya koordinasi yang efektif dan efisien dalam tugas pemulihan.

3. Meminimumkan gangguan bencana terhadap kegiatan sehari-hari.

4. Membatasi perluasan kerusakan dan mencegah terjadinya bencana lebih luas.

5. Menyusun operasi alternatif.

6. Menyediakan jasa dan operasi pemullihan yang lancar dan cepat.

7. Mencegah luka terhadap personel dan masyarakat.

8. Mencegah kerusakan terhadap harta benda instansi atau perusahaan.

9. Meminimumkan dampak ekonomi.

10. Menjamin kelangsungan instansi atau perusahaan akibat terjadinya bencana.

Selanjutnya Sulistyo-Basuki (2013:6.16) menyatakan bahwa rencana pencegahan dan pemulihan bencana meliputi langkah-langkah berupa persetujuan dan keterikatan pada rencana, membentuk tim anti bencana, dan mengumpulkan informasi yang diperlukan untuk menjalankan rencana manakala benar-benar terjadi bencana. Selain itu, upaya mencegah dan memulihkan bencana memerlukan sumber daya tambahan karena itu perlu persetujuan dan keterikatan manajemen puncak. Upaya tersebut dapat didukung dengan adanya analisis manfaat biaya (cost benefit analysis) dan penilaian risiko (risk assesment) serta menyajikannya dengan bantuan berbagai media kepada manajemen puncak.

Menurut Harvey (1993:123), adapun tahapan-tahapan/elemenelemen dari rencana untuk mengahadapi sebelum terjadinya bencana, yaitu sebagai berikut:

1. Pencegahan

Pencegahan dibutuhkan kesiapan dari petugas perpustakaan akan adanya risiko bencana yang mungkin saja mengancam perpustakaan. Tujuan tahap pencegahan ini adalah untuk mengidentifikasi penyebab bencana dan untuk memperkecil risiko yang dihadapi oleh gedung 
perpustakaan itu sendiri, yaitu peralatan penyimpanan dan perabotannya. Tahapan tersebut meliputi berbagai kegiatan prosedur atau peralatan yang disiapkan untuk mencegah terjadinya bencana. Tahapan pencegahan ini, yaitu sebagai berikut:

a. Pemeriksaan bangunan (tempat penyimpanan, peralatannya).

b. Pemeriksaan perlindungan terhadap kebakaran dan alat pendeteksi, juga alat pendeteksi pencurian.

c. Pembuatan back-up atau salinan duplikat termasuk katalognya.

d. Mengasuransikan, premi akan berkurang bila tindakan pencegahan ditngkatkan.

2. Tanggapan

Tanggapan merupakan tahap kedua untuk menghadapi sebelum terjadinya bencana. Tanggapan ini mencakup berbagai kegiatan atau program dan sistem yang diterapkan sebelum keadaan darurat. Tahapan ini meliputi beberapa hal, yaitu sebagai berikut:

a. Penetapan dan pelatihan staf

b. Identifikasi koleksi dan memberikan prioritas utama pada koleksi langka

c. Pemeliharaan peralatan yang digunakan untuk penyelamatan koleksi

d. Mendaftar nama dan lembaga penting yang harus dihubungi jika terjadi bencana, dan

e. Membuat prosedur rencana penanggulangan bencana.

3. Reaksi

Reaksi merupakan tahap ketiga, tahap reaksi ini merupakan kegiatan yang dilakukan jika benar-benar sudah terjadi bencana. Tahap reaksi ini berhubungan langsung dengan arah penentuan kebijakan, yang meliputi, yaitu sebagai berikut:

a. Menentukan langkah prosedur yang dilakukan ketika terjadi bencana

b. Memastikan lokasi bencana aman dimasuki

c. Dan memindahkan materi yang rusak.

4. Pemulihan 
Pemulihan merupakan tahap terakhir, tahap pemulihan ini mencakup aktivitas atau bantuan jangka panjang untuk memulihkan kembali sistem yang lumpuh atau terganggu selama bencana. Tahap pemulihan ini meliputi beberapa hal, yaitu sebagai berikut:

a. Penetapan dan pelaksanaan program memperbaiki lokasi bencana dan materi yang rusak

b. Mengambil teknik penyelamatan terhadap koleksi

c. Menganalisi bencana dan perbaikan rencana bencana

Adapun menurut Muttaqin, dkk (2007:6) persiapan menghadapi bencana/disaster preparedness, perlu penyusunan rencana strategis, adapun penyusunan rencana strategis tersebut, yaitu sebagai berikut:

a. Buat organisasi penanganan bencana

b. Optimalkan gerakan lumbung masyarakat

c. Tentukan tempat pengungsian dan posko koordinasi bantuan dan rute evakuasi

d. Siapkan kotak/tas siaga

e. Siapkan kemampuan teknis (technical skill)

f. Telpon untuk gawat darurat

g. Kenalilah nomor telepon dan alamat untuk lembaga penanganan bencana di wilayah anda.

Sedangkan menurut Sulistyo-Basuki (2013:6.27) metode penyelamatan tergantung pada penyebab kerusakan masing-masing walaupun kerusakan terbesar karena air. Adapun metode penyelaman terhadap rekod yaitu:

1. Vacuum freeze drying

Vacuum freeze drying adalah proses penyelamatan materi, materi kertas dibekukan, kemudian dikeringkan dalam sebuah ruang panas. Metode ini merupakan metode yang paling aman dan paling berhasil, tetapi juga paling mahal.

2. Vacuum drying 
Vacuum drying merupakan sebuah proses, dalam proses tersebut materi yang basah ditempatkan dalam sebuah ruangan yang menarik embun dengan cara penghampaan. Metode ini tidak dianjurkan karena suhu panas merusak materi kertas dan foto.

3. Pembekuan (freezing)

Dalam proses pembekuan, kertas yang basah dimasukkan ke ruangan yang bersuhu dibawah titik beku, membiarkannya beku beberapa lama, kemudian baru ditentukan langkah lebih lanjut. Suhu tersebut di bawah $-28^{\circ} \mathrm{C}$ akan membekukan dan mengeringkan materi yang basah.

4. Pengeringan bantuan udara

Pengeringan udara hanya boleh dilakukan dalam lingkungan yang stabil guna mencegah pertumbuhan lumut. Lingkungan yang ideal untuk pengeringan udara ialah $10^{\circ}-12^{\circ}$ Celcius dan kelembapan relatif $25-35 \%$.

\section{METODE PENELITIAN}

Adapun metode yang digunakan untuk memperoleh data dalam penelitian ini adalah metode deskriptif dengan pendekatan penelitian kualitatif. Informan kunci dalam penelitian ini adalah dengan Kepala Perpustakaan Fakultas Peternakan UGM yaitu Bapak Tri Septiyantono. Adapun teknik-teknik yang peneliti gunakan dalam upaya pengumpulan data yaitu, observasi non partisipan, wawancara mendalam dan dokumentasi. Untuk teknik analisis data yang peneliti gunakan dalam penelitian ini sesuai dengan menurut Miles dan Huberman dalam Sugiyono (2005:91) yaitu meliputi: pengumpulan data, reduksi data, display data (penyajian data), penarikan kesimpulan dan verifikasi. 


\section{PEMBAHASAN DAN HASIL PENELITIAN}

\section{A. Upaya yang direncanakan untuk menyelamatkan koleksi dalam} rangka menghadapi bencana alam di Perpustakaan Fakultas Peternakan Universitas Gadjah Mada (UGM) Yogyakarta

Dalam usaha menghadapi bencana alam terlebih dahulu perpustakaan harus melakukan tahap perencanaan penyelamatan bagi koleksi perpustakaan. Menurut Syaiful Sagala Perencanaan adalah proses memikirkan dan menetapkan kegiatan-kegiatan atau programprogram yang akan dilakukan di masa yang akan datang untuk mencapai tujuan tertentu. Di perpustakaan Fakultas Peternakan Universitas Gadjah Mada Yogyakarta, telah melaukan usaha atau kegiatan-kegiatan yang dilakukan dalam upaya penyelamatan koleksi, seperti telah melakukan program back up data koleksi perpustakaan dan pelatihan bagi karyawan perpustakaan. Yang menjadi prioritas utama dalam usaha penyelamatan koleksi di perpustakaan adalah koleksi Repository karena perpustakaan beranggapan bahwa hasil karya mahasiswa merupakan koleksi yang paling penting untuk Fakultas Peternakan karena sewaktu-waktu pasti digunakan untuk proses akreditasi, maka dari itu koleksi tersebut perlu di back up. Sedangkan untuk koleksi tercetak di perpustakaan belum dilakukan alih media maupun back up data, karena berdasarkan penuturan dari Bapak Tri Septiyantono bahwa koleksi fisik apabila rusak baik disebabkan oleh bencana maupun termakan usia masih bisa dicari bentuk fisiknya melalui kegiatan pengadaan koleksi di perpustakaan.

Penulis telah merangkum hasil dari penelitian tentang "Upaya Perencanaan Penyelamatan Koleksi dalam Rangka Menghadapi Bencana Alam di Perpustakaan Fakultas Peternakan Universitas Gadjah Mada (UGM) Yogyakarta” berdasarkan dari teori yang dikemukan oleh Harvey (1993). Menurut Harvey (1993) ada 4 tahapan dalam perencanaan mengahadapi sebelum terjadinya bencana.

1. Pencegahan 
Dari teori yang dikemukakan oleh Harvey, dikemukakan bahwa tahap pencegahan merupakan upaya untuk mengidentifikasi penyebab terjadinya bencana dan untuk memperkecil risiko yang dihadapi oleh gedung perpustakaan itu sendiri. Perpustakaan Fakultas Peternakan Universitas Gadjah Mada Yogyakarta telah melakukan tahap-tahap dari pencegahan dengan melakukan pemeriksaan bangunan tempat penyimpanan koleksi, gedung perpustakaan telah dijamin kekuatannya dari getaran gempa bumi, dan melakukan pemeriksaan terhadap gedung supaya terhindar dari kebakaran.

2. Tanggapan

Tanggapan merupakan tahap kedua untuk menghadapi sebelum terjadinya bencana. Tanggapan ini mencakup berbagai kegiatan atau program dan sistem yang diterapkan sebelum keadaan darurat. Adapun kegiatan yang dilakukan oleh Perpustakaan Fakultas Peternakan Universitas Gadjah Mada dalam usaha sebelum terjadinya bencana yaitu dengan melakukan pelatihan bagi pustakawan sebelum terjadinya bencana alam, kegiatan tersebut dilaksanakan oleh Fakultas Peternakan yang ditujukan kepada semua karyawan Fakultas Peternakan termasuk Pustakawan Perpustakaan Fakultas Peternakan Universitas Gadjah Mada Yogyakarta. Jadi, tidak ada pustakawan yang ditunjuk khusus untuk penyelamatan koleksi ketika bencana terjadi. Pada kegiatan pelatihan penanggulangan ketika terjadinya bencana pustakawan ditunjukkan jalur evakuasi yang ada di perpustakaan dan pintu darurat yang hanya dibuka ketika terjadi kebakaran, gempa bumi dan bencana lainnya.

3. Reaksi

Reaksi merupakan tahap ketiga, tahap reaksi ini merupakan kegiatan yang dilakukan jika benar-benar sudah terjadi bencana. Meskipun Perpustakaan Fakultas Peternakan Universitas Gadjah Mada belum meiliki prosedur secara tertulis tentang cara menghadapi bencana alam namun apabila benar-benar terjadinya bencana alam di 
perpustakaan, pustakawan telah mengtahui langkah apa yang harus dilakukan pertama kali, misalnya yaitu melakukan menyelamatan bagi pengunjung perpustakaan dengan mengarahkan mereka pada jalur evakuasi dan pintu darurat yang terdapat di perpustakaan. Kemudian setelah semua orang di perpustakaan berhasil diselamatkan langkah selanjutnya yaitu menyelamatkan koleksi yang ada di perpustakaan apabila lokasi sudah dinyatakan aman. Langkah selanjutnya yaitu, pihak perpustakaan akan berupaya menyelamatkan koleksi yang dianggap penting yang wajib untuk diselamatkan. Menurut bapak Tri Septiyantono, perpustakaan Fakultas Peternakan Universitas Gadjah Mada sudah melakukan pemindahan koleksi yang rusak, dan koleksi yang rusak tersebut di pindahkan dan di perbaiki pasca terjadinya bencana alam.

4. Pemulihan

Pemulihan merupakan tahap terakhir, tahap pemulihan ini mencakup aktivitas atau bantuan jangka panjang untuk memulihkan kembali sistem yang lumpuh atau terganggu selama bencana. Di perpustakaan Fakultas Peternakan Universitas Gadjah Mada untuk perbaikan koleksi dilakukan berdasarkan tingkat kerusakan dari koleksi tersebut. Jadi, apabila koleksi tersebut rusak ringan maka akan di perbaiki secepatnya, namun apabila kerusakan mencapai 50\% maka koleksi tersebut akan dilakukan pengadaan kembali melalui pengadaan koleksi. Teknik yang digunakan dalam upaya penyelamatan koleksi di perpustakaan Fakultas Peternakan UGM tidak ada tknik secara khusus. Koleksi yang rusak didata berdasarkan judul, kemudian untuk koleksi yang rusak lebih dari 50\% dilakukan pengadaan kembali. Sedangkan untuk koleksi yang rusak ringan cukup di perbaiki seperlunya oleh pihak perpustakaan. Pasca terjadinya bencana alam tidak dilakukan analisis mendalam tentang kerugian yang ditimbulkan oleh bencana, baik bencana yang disebabkan oleh gempa bumi, kebakaran dan sebagainya. Namun, biasanya berdasarkan hasil 
wawancara dengan Bapak Tri Septiyantono untuk pengadaan koleksi yang rusak mendapat bantuan dari pemerintah.

B. Proses penyelamatan koleksi dalam rangka menghadapi bencana alam di perpustakaan Fakultas Peternakan Universitas Gadjah Mada (UGM) Yogyakarta

Proses penyelamatan koleksi sebelum terjadinya bencana alam pihak perpustakaan Fakultas Peternakan Universitas Gadjah Mada (UGM) Yogyakarta telah mem-back up seluruh data koleksi yang di anggap penting. Back up data tersebut disimpan pada tiga (3) tempat yang berbeda yaitu disimpan di luar Kota Yogyakarta, di Perpustakaan Pusat dan disimpan oleh kepala perpustakaan. Di perpustakaan Fakultas Peternakan Universitas Gadjah Mada (UGM) koleksi yang menjadi prioritas utama untuk diselamatkan dari ancaman bencana alam yaitu koleksi karya akhir mahasiswa seperti skripsi, tesis dan disertasi yang dinamakan koleksi repository. Dari tahun 2005 perpustakaan telah melakukan penyelamatan terhadap koleksi repository dengan melakukan back up data yang disimpan tidak hanya di perpustakaan saja.

Untuk pemeliharaan terhadap peralatan yang digunakan pada saat bencana alam terjadi dilakukan oleh karyawan Fakultas Peternakan Universitas Gadjah Mada (UGM) dengan melakukan pengecekan alat setiap awal bulan, untuk melihat kondisi apakah alat tersebut masih layak digunakan atau tidak apabila ketika sewaktuwaktu terjadi bencana alam.

C. Alat yang sudah tersedia untuk menyelamatkan koleksi dalam rangka menghadapi bencana alam di Perpustakaan Fakultas Peternakan Universitas Gadjah Mada (UGM) Yogyakarta

Fakultas Peternakan Universitas Gadjah Mada (UGM) Yogyakarta, untuk saat ini peralatan yang dimiliki hanya alat pemadam kebakaran, 
yaitu berupa dua (2) unit alat pemadam kebakaran yang terletak di dalam ruang perpustakaan, satu (1) unit pipa penyalur air, dan 1 hydran yang digunakan untuk menyalurkan air ketika terjadinya kebakaran. Sedangkan untuk alat pendeteksi bencana alam perpustakaan belum memilikinya. Namun, untuk meningkatkan kewaspadaan terhadap bencana alam hingga saat ini perpustakaan baru menyediakan alat pemadam kebakaran saja. Adapun Alat yang dimiliki oleh perpustakaan tersebut, yaitu bisa dilihat pada gambar di bawah ini:

Tabung Pemadam Kebakaran

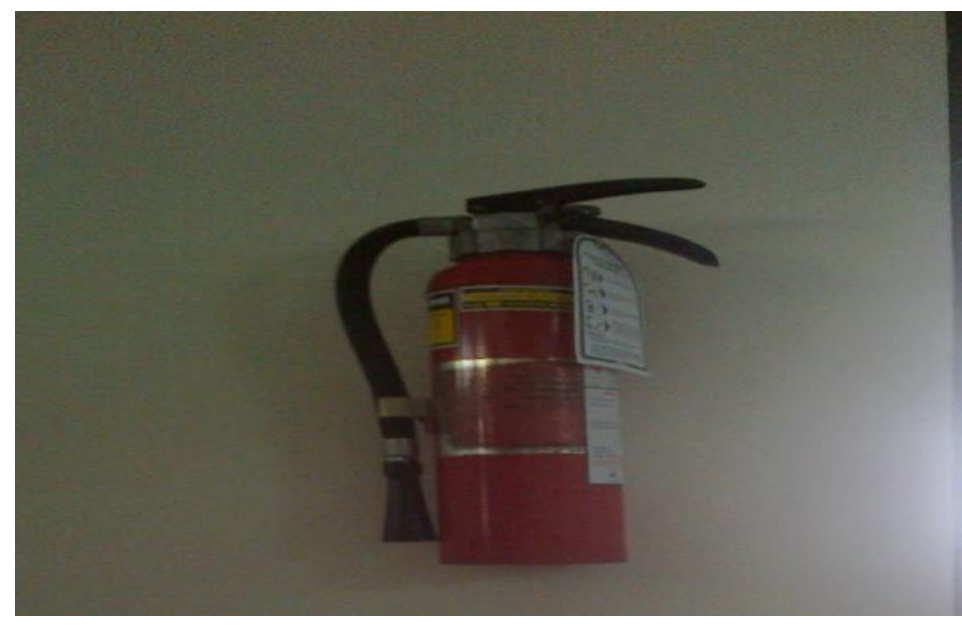

Alat Penyalur Air (Hidrant)

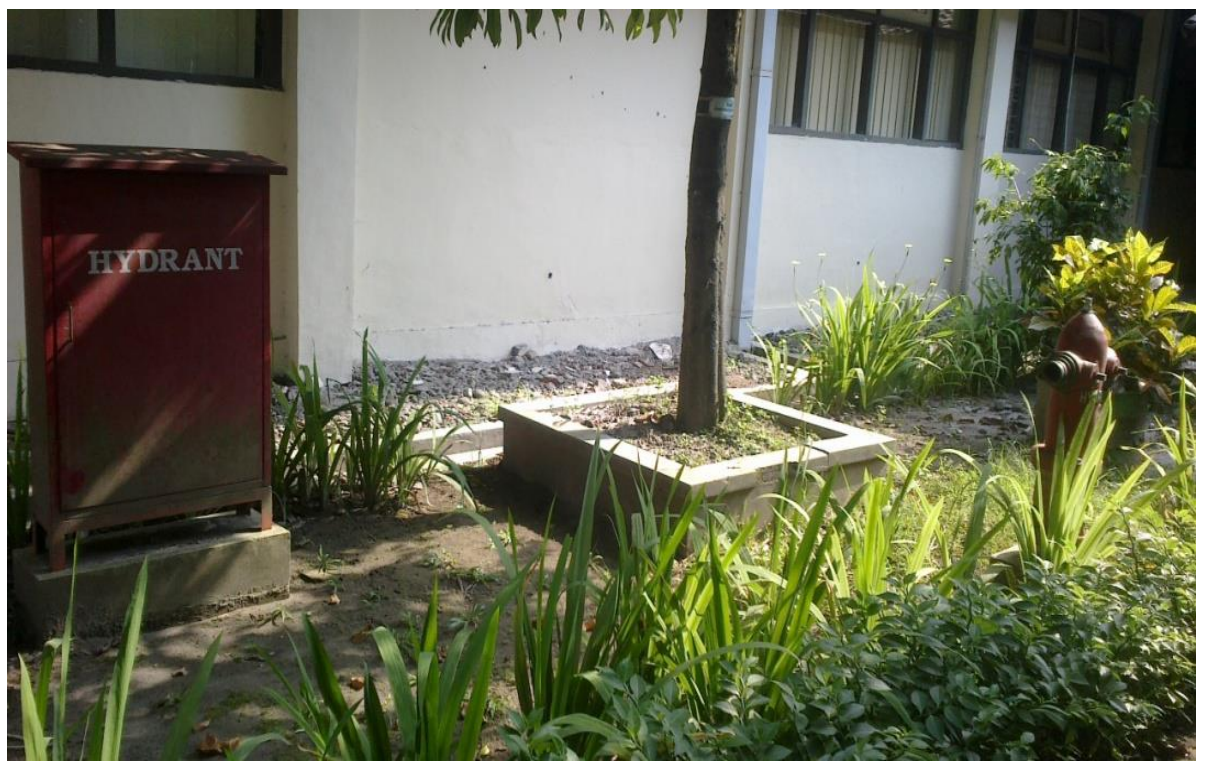




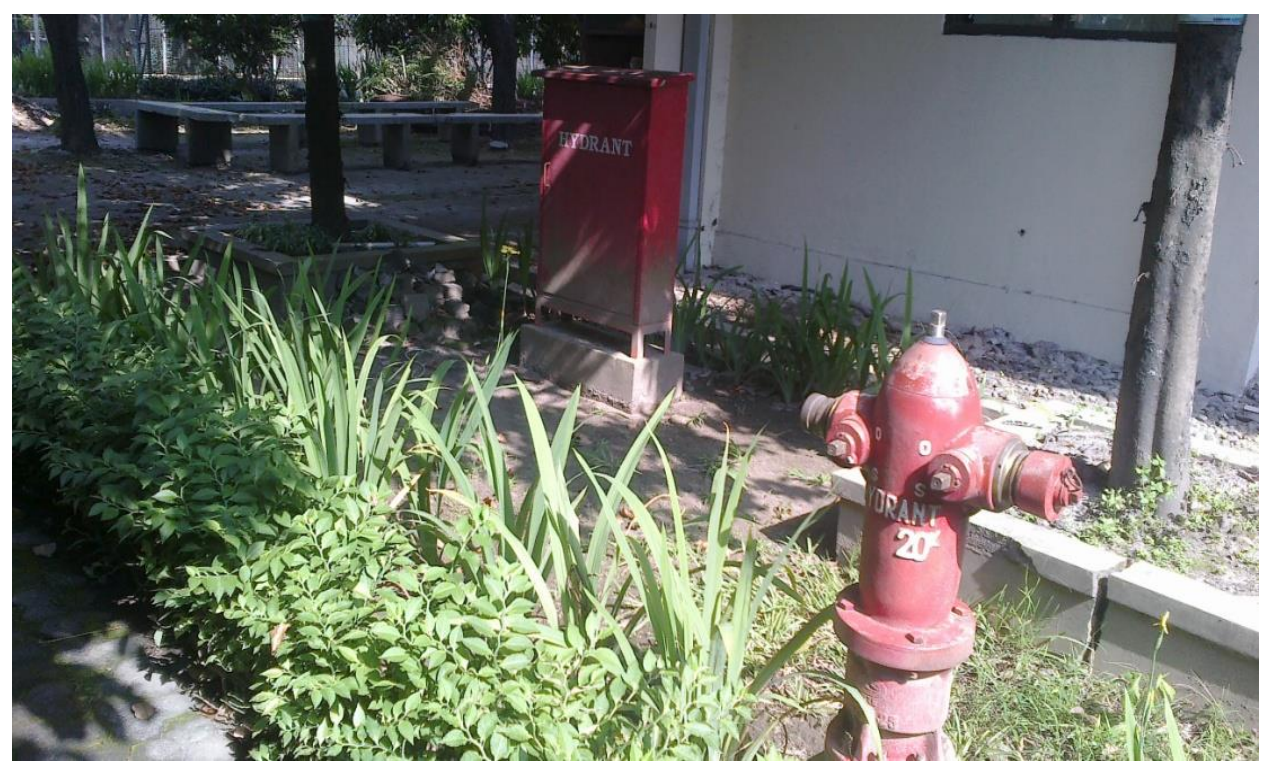

Perpustakaan Fakultas Peternakan Universitas Gadjah Mada (UGM) Yogyakarta, untuk saat ini belum memiliki prosedur secara tertulis tentang rencana penanggulangan bencana, karena prosedur tentang rencana penanggulangan bencana baru dalam tahap penyempurnaan. Apabila terjadi bencana kebakaran pihak pertama yang dihubungi oleh perpustakaan ialah Unit Pemadam Kebakaran yang dimiliki oleh Universitas Gadjah Mada Yogyakarta. Sedangkan untuk keamanan gedung perpustakaan, berdasarkan wawancara dengan Kepala Perpustakaan yaitu Bapak Tri Septiyantono gedung perpustakaan Fakultas Peternakan UGM termasuk kuat dari getaran gempa bumi namun dengan skala yang rendah. Jadi, setiap unit di Fakultas Peternakan UGM termasuk perpustakaan telah diberi sebuah buku telf yang diperoleh dari pusat, untuk keperluan di setiap unit, termasuk siapa yang harus dihubungi pada saat terjadinya bencana alam. Adapun buku telpon yang dimiliki oleh perpustakaan tersebut, yaitu bisa dilihat pada gambar di bawah ini: 


\section{Buku Telpon}

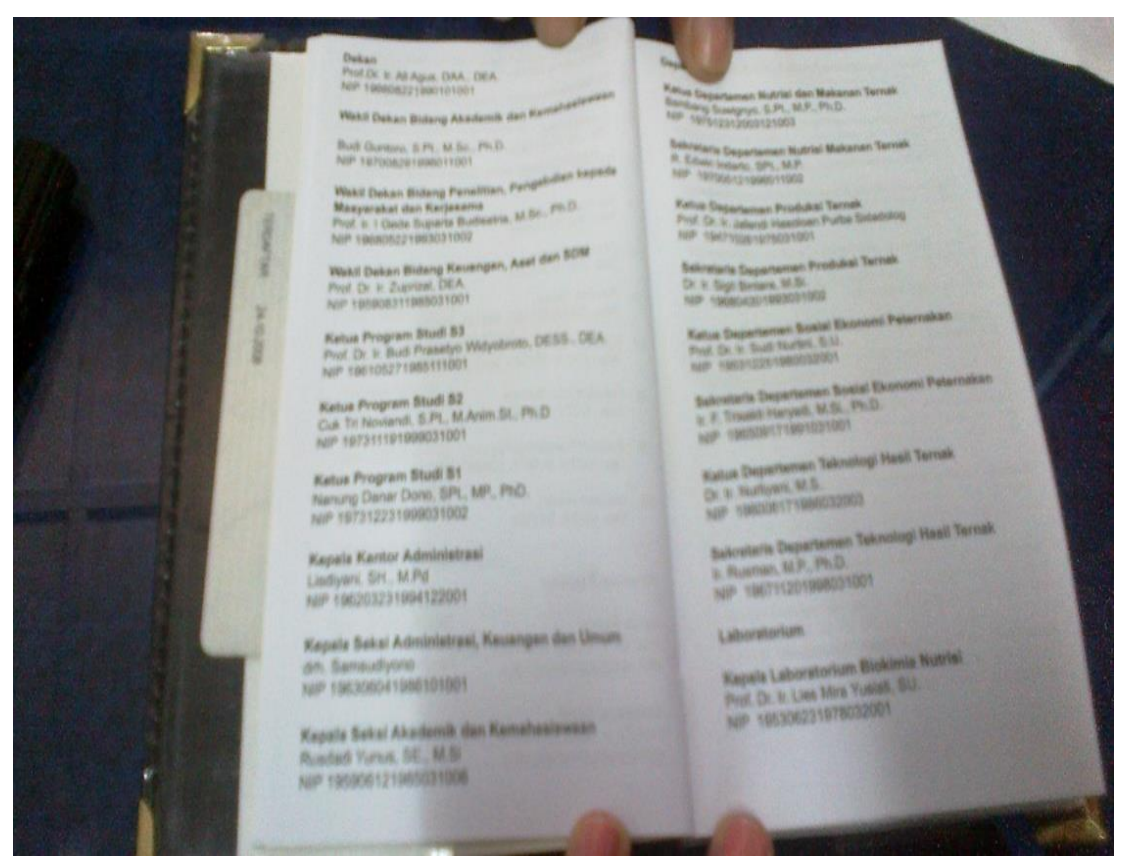

\section{PENUTUP}

\section{A. Kesimpulan}

Upaya yang direncanakan untuk menyelamatkan koleksi dalam rangka menghadapi bencana alam di Perpustakaan Fakultas Peternakan Universitas Gadjah Mada (UGM) Yogyakarta yaitu ada empat (4) tahap. Pertama, tahap pencegahan yaitu dengan melakukan pengecekan terhadap ruang dan peralatan yang dimiliki oleh perpustakaan serta meyediakan alat yang bisa digunakan ketika terjadi bencana. Kedua, tahap tanggapan yaitu dengan melakukan kegiatan seperti pelatihan staf, mem-back up koleksi yang dianggap penting, perawatan dan pengecekan alat yang digunakan pada saat terjadinya bencana, dan upaya penyusunan prosedur tentang penanggulangan bencana secara tertulis. Ketiga, tahap reaksi, meskipun belum memiliki prosedur secara tertulis. Namun, melalui pelatihan staff perpustakaan telah mengetahui apa yang harus dilakukan pada saat sedang terjadinya bencana alam. Keempat, tahap pemulihan, pasca terjadinya 
bencana Perpustakaan akan memperbaiki koleksi yang ringan secepatnya sedangkan untuk koleksi yang rusak berat tidak akan diperbaiki tapi akan dilakukan pengadaan kembali.

Untuk proses penyelamatan sebelum terjadinya bencana, perpustakan Fakultas Peternakan melakukan back-up untuk koleksi yang di anggap penting, karena prioritas utama adalah koleksi repositori maka, sejak tahun 2005 perpustakaan telah melakukan back up data yang disimpan di tiga (3) server yang berbeda yaitu, di luar kota Yogyakarta, di server perpustakaan pusat dan disimpan oleh kepala Perpustakaan Peternakan Universitas Gadjah Mada (UGM) Yogyakarta. Adapun alat yang dimiliki oleh Perpustakaan Fakultas Peternakan Universitas Gadjah Mada (UGM) Yogyakarta hingga saat ini baru tersedia alat pemadam kebakaran yaitu dua (2) unit alat pemadam kebakaran yang terletak di dalam ruang perpustakaan, satu (1) unit pipa penyalur air, dan 1 hydran yang digunakan untuk menyalurkan air ketika terjadinya kebakaran. Sedangkan untuk alat pendeteksi bencana alam perpustakaan belum memilikinya.

\section{B. Saran}

1. Perpustakaan Fakultas Peternakan Universitas Gadjah setidaknya memiliki satu alat pendekteksi bencana, misalkan alat pendeteksi bencana kebakaran, karena melihat Perpustakaan Fakultas Peternakan Universitas Gadjah Mada yang terletak di antara gedung-gedung yang rawan terkena kebakaran.

2. Perpustakaan Fakultas Peternakan Universitas Gadjah harus memiliki kebijakan tertulis dalam upaya penyelamatan koleksi di perpustakaan, supaya pada saat bencana alam terjadi apa yang harus dilakukan oleh pustakawan menjadi lebih mudah untuk dilakukan.

3. Perpustakaan Fakultas Peternakan Universitas Gadjah Mada harus memiliki kebijakan secara tertulis tentang penyelamatan koleksi perpustakaan baik sebelum maupun setelah terjadinya bencana alam. 
4. Perpustakaan Fakultas Peternakan Universitas Gadjah Mada perlu menambah alat bantu yang digunakan dalam upaya penanggulangan bencana alam. 


\section{DAFTAR PUSTAKA}

Badudu. Muhammad Zain, Sultan. Kamus Umum Bahasa Indonesia. Jakarta: Pustaka Sinar Harapan. 1994.

Dureau, J.M. dan D.W.G. Clements, Dasar-Dasar Pelestarian dan Pengawetan Bahan-Bahan Pustaka. Jakarta: Perpustakaan Nasional. 1990.

Fatmawati, Endang. The Art of Library Ikatan Esai Bergizi Tentang Seni Mengelola Perpustakaan. Semarang: Universitas Diponegoro Semarang. 2010.

Harvey, Ros. Preservation in Libraries: Principles, Strategies, and Practice for Librarias. London: Bowker-Saur. 1993.

Kamus Besar Bahasa Indonesia. Jakarta: Balai Pustaka. 1989.

Kohar, Ade. Teknik Penyusunan Kebijakan Pengembangan Koleksi Perpustakaan: Suatu Implementasi Studi Retrospektif. Jakarta: Citra Aditya. 2003.

Krihanta. Pengelolaan Arsip Vital. Tanggerang Selatan: Universitas Terbuka. 2013.

Lasa HS. Kamus Kepustakawanan Indonesia. Yogyakarta: Pustaka Book Publisher. 2009.

Muttaqin, Ahmad. Dkk. Cerdas Menghadapi Bencana: Persiapan, Penanganan dan Tips Menghadapi Bencana Alam. Yogyakarta: Center for the Study of Islam and Social Transformation (CISForm) Universitas Islam Negeri (UIN) Sunan Kalijaga. 2007.

Rewaju Issa, Abdul Wahab Olan. "Disaster Preparedness at the State Public Library Ilorin Kware State". Dalam Http://Unllib. Unl. Edu/LPP/, Diakses Pada Tanggal 30 April 2015. Pukul 12:45.

Sagala, Syaiful. Manajemen Strategik dalam Peningkatan Mutu Pendidikan. Cet Ke-4 Bandung: Alfabeta. 2010.

Sugiyono. Memahami Penelitian Kualitatif. Bandung: Alfabeta. 2005. 
Sulistyo-Basuki. Pengantar Ilmu Kearsipan. Tanggerang Selatan: Universitas Terbuka. 2013.

Undang-Undang Republik Indonesia Nomor 43 Tahun 2007 Tentang Perpustakaan. Jakarta: Perpustakaan Nasional RI. 2007.

WJS. Poerwadarminta. Kamus Umum Bahasa Indonesia. Jakarta: Balai Pustaka. 2011.

Wawancara dengan Bapak Tri Septiyantono, M.Si (Kepala Perpustakaan Fakultas Peternakan Universitas Gadjah Mada Yogyakarta) pada Jum'at, 08 Mei 2015 Pukul 13.35 WIB. 